\title{
Molecular and clinical characteristics of Hemoglobin Ottawa detected in a Chinese population
}

\author{
YUE HUANG, MIN LIN, CHUN-PING LIN, JIAO-REN WU, LUO-HAN ZHENG and LI-YE YANG \\ Department of Central Laboratory, Chaozhou Central Hospital, Chaozhou, Guangdong 521021, P.R. China
}

Received February 7, 2011; Accepted March 21, 2011

DOI: $10.3892 / \mathrm{mmr} .2011 .467$

\begin{abstract}
Hemoglobin (Hb) Ottawa [ $\alpha 15$ (A13) Gly $\rightarrow$ Arg], also known as $\mathrm{Hb}$ Siam, was first described in an 82-year-old Canadian in 1974. The same year, a second case was reported in a 28 -year-old Chinese male living in Thailand. A third case was found in 1986 in a Chinese female living in the Hubei province of China. Since then, there have been no reports of $\mathrm{Hb}$ Ottawa in mainland China in the English literature. $\mathrm{Hb}$ Ottawa results from a GGT $\rightarrow$ CGT mutation in codon 15 of the $\alpha_{1}$ or $\alpha_{2}$-globin gene. Hb Ottawa carriers do not present any clinical symptoms or hematological changes, and are often diagnosed during a health examination and thalassemia screening. In a hemoglobin survey of 9745 students in Chaozhou, Guangdong, China, we identified four cases of $\mathrm{Hb}$ Ottawa in a thalassemia screening by $\mathrm{Hb}$ electrophoresis, and confirmed it to be the result of a GGT $\rightarrow$ CGT mutation in codon 15 of the $\alpha_{2}$-globin gene by DNA sequence analysis.
\end{abstract}

\section{Introduction}

Hemoglobin (Hb) Ottawa [ $\alpha 15$ (A13) Gly $\rightarrow$ Arg], also known as Hb Siam, was first identified in an 82-year-old Canadian (1). The same year, a second case was reported in a 28 -year-old Chinese male living in Thailand (2). According to the human hemoglobin variant database (HbVar) (http://globin.cse.psu. edu), $\mathrm{Hb}$ Ottawa has only been found in individuals of PolishCanadian and Chinese ethnicity. Hb Ottawa results from a GGT $\rightarrow$ CGT mutation in codon 15 of the $\alpha_{2}$-globin gene (1-3), although some studies have reported that it is a result of a GGT $\rightarrow$ CGT mutation in the $\alpha_{1}$-globin gene $(4,5)$. Hb Ottawa carriers do not present any clinical symptoms or hematological changes, and are often diagnosed in thalassemia screening by $\mathrm{Hb}$ electrophoresis, confirmed by DNA sequence analysis.

In 1986, a case of $\mathrm{Hb}$ Ottawa was found in a Chinese female in the Hubei province of China. This was the first

Correspondence to: Li-Ye Yang, Department of Central Laboratory, Chaozhou Central Hospital, Chaozhou, Guangdong 521021, P.R. China

E-mail: yangleeyee@sina.com

Key words: hemoglobinopathy, Hemoglobin Ottawa report of $\mathrm{Hb}$ Ottawa in China (3). Since then, there have been no reports of $\mathrm{Hb}$ Ottawa in mainland China in the English literature. Recently, during a hemoglobin survey of 9745 students in Chaozhou, Guangdong, China, we identified four cases of Hb Ottawa in a thalassemia screening by $\mathrm{Hb}$ electrophoresis, and confirmed it to be the result of a GGT $\rightarrow$ CGT mutation in codon 15 of the $\alpha_{2}$-globin gene by DNA sequence analysis.

\section{Materials and methods}

Materials. During a hemoglobin survey of 9745 students aged 7-19 years in Chaozhou, Guangdong, China, four cases of abnormal hemoglobin were found by $\mathrm{Hb}$ electrophoresis.

Hematological analysis. The specimens were analyzed by cellulose acetate electrophoresis $(\mathrm{pH} 8.6)$, and the percentage of $\mathrm{Hb}$ variants was measured by densitometry on alkaline electrophoresis (6). Hb stability was examined by the isopropanol and heat methods $(7,8)$. Hb variants were dissociated by parachloro-mercuri-benzoate (PCMB), which is capable of differentiating $\alpha$ - or $\beta$-globin mutations (9).

DNA analysis. Genomic DNA was extracted from the peripheral blood leukocytes of the specimens using the genomic DNA mini-preparation kit (Decipher Bioscience Shenzhen Ltd.) according to previously described methods (10). The $\alpha_{1}$ and $\alpha_{2}$ globin genes were separately amplified by polymerase chain reaction $(\mathrm{PCR})$ in the DNA thermal cycler $\mathrm{MJ}$ mini (Bio-Rad, Hercules, CA, USA). The primers and products lengths are shown in Table I, and were determined as described previously $(11,12)$.

The $\alpha_{1}$-globin gene was amplified in $50 \mu \mathrm{l}$ PCR reaction mixtures containing $0.1 \mu \mathrm{g}$ DNA, 15 pmol primers, $200 \mu \mathrm{mol}$ dNTPs and 2.5 units Taq DNA polymerase (Shanghai Sangon Biological Engineering Technology and Services Co., Ltd., P.R. China) in $10 \mathrm{mmol} / \mathrm{l}$ Tris- $\mathrm{HCl}$ (pH 8.0), $50 \mathrm{mmol} / \mathrm{l} \mathrm{KCl}$ and $3 \mathrm{mmol} / 1 \mathrm{MgCl}_{2}$. PCR conditions were as follows: after an initial denaturation at $95^{\circ} \mathrm{C}$ for $3 \mathrm{~min}$ to activate the DNA polymerase, 35 cycles of PCR at $98^{\circ} \mathrm{C}$ for $40 \mathrm{sec}, 60^{\circ} \mathrm{C}$ for $5 \mathrm{sec}$ and $72^{\circ} \mathrm{C}$ for $1 \mathrm{~min}$ were carried out, followed by a final extension at $72^{\circ} \mathrm{C}$ for $5 \mathrm{~min}$. The amplification process was similar for the $\alpha_{2}$-globin and $\alpha_{1}$-globin genes. The amplified products were separated on $2 \%$ agarose gels and detected under UV light after staining with ethidium bromide. The 


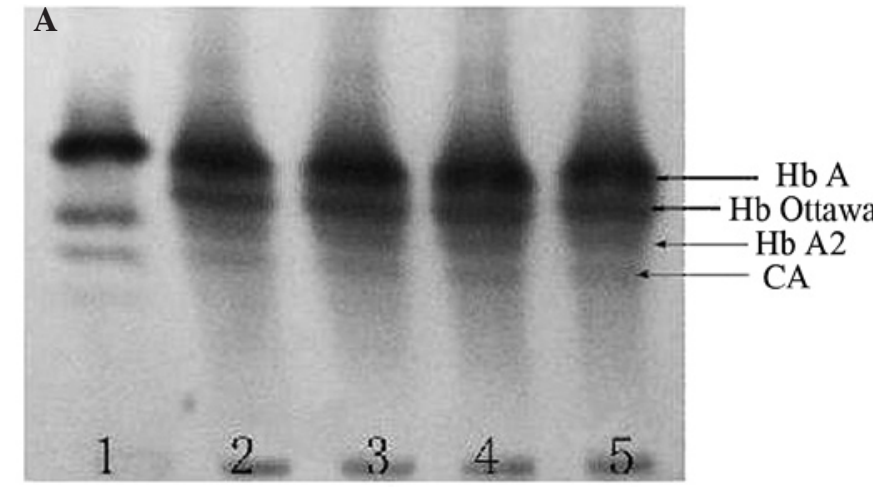

B

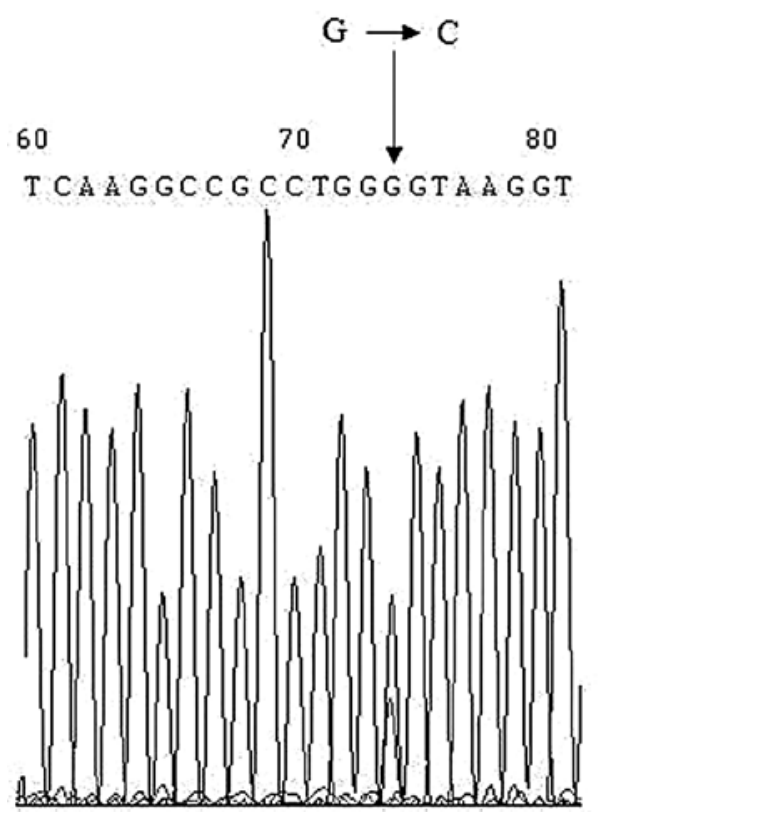

Figure 1. Hemoglobin electrophoresis and DNA sequencing analysis. (A) Hemoglobin analysis with cellulose acetate electrophoresis at $\mathrm{pH}$ 8.6. 1, Normal control; 2, Case 1; 3, Case 2; 4, Case 3; 5, Case 4; (B) DNA sequence analysis of the amplified $\alpha_{2}$-globin gene. The downward arrow indicates the $\mathrm{G} \rightarrow \mathrm{C}$ substitution in codon 15 of the $\alpha_{2}$-globin gene.
Table I. Primers and length of globin gene amplification.

\begin{tabular}{llc}
\hline Primers & \multicolumn{1}{c}{$\begin{array}{c}\text { Sequences } \\
\left(5^{\prime}-3^{\prime}\right)\end{array}$} & $\begin{array}{c}\text { PCR product length } \\
(\mathrm{bp})\end{array}$ \\
\hline$\alpha_{1}-\mathrm{B}$ & $\begin{array}{c}\text { CCATGCCTGGCA } \\
\text { CGCTTTGCTGAG }\end{array}$ & 880 \\
$\alpha_{1}-\mathrm{L}$ & TCCCCACAGACT & \\
& CAGAGAGAACC & \\
$\alpha_{2}-\mathrm{D}$ & AACACCTCCATTC & \\
& GTTGGCACATTC & \\
$\alpha_{2}-\mathrm{L}$ & TCCCCACAGACT & \\
& CAGAGAGAACC & \\
\hline
\end{tabular}

PCR products were analyzed by DNA sequencing with the ABI 3700 automated sequencer.

\section{Results}

During a hemoglobin survey of 9745 students aged 7-19 years in Chaozhou, Guangdong, China, four cases of abnormal hemoglobin were identified by $\mathrm{Hb}$ electrophoresis. The subjects had no clinical symptoms or hematological changes. The hematological data are summarized in Table II. The Hb variant patterns were revealed by $\mathrm{Hb}$ cellulose acetate electrophoresis at pH 8.6 (Fig. 1A). This Hb variant (about $15 \%$ of total $\mathrm{Hb}$ ) migrated toward the anode faster than $\mathrm{Hb}$ A2 and slower than $\mathrm{Hb} \mathrm{A}$, and the distance between it and $\mathrm{Hb} \mathrm{A} 2$ was equal to that of the distance between it and $\mathrm{Hb} \mathrm{A}$. The results of $\mathrm{Hb}$ stability tests were normal. After the $\alpha_{1}$ and $\alpha_{2}$-globin genes were amplified and their PCR products were sequenced, a transition from $\mathrm{G} \rightarrow \mathrm{C}$ in codon 15 of the $\alpha_{2}$-globin gene was observed (Fig. 1B). These results revealed that the identified subjects were $\mathrm{Hb}$ Ottawa carriers.

Table II. Summary of hematological findings.

\begin{tabular}{|c|c|c|c|c|}
\hline Parameter & Case 1 & Case 2 & Case 3 & Case 4 \\
\hline $\operatorname{RBC}\left(10^{12} / 1\right)$ & 5.30 & 5.38 & 4.9 & 4.99 \\
\hline $\mathrm{Hb}(\mathrm{g} / \mathrm{l})$ & 145.00 & 160.00 & 136.0 & 132.00 \\
\hline MCV (fl) & 87.30 & 87.40 & 84.4 & 89.30 \\
\hline HCT (\%) & 46.80 & 47.00 & 41.3 & 44.50 \\
\hline MCH (pg) & 27.30 & 29.70 & 27.7 & 26.40 \\
\hline MCHC (g/l) & 313.00 & 340.00 & 329.0 & 296.00 \\
\hline RDW (\%) & 13.30 & 13.60 & 15.7 & 13.50 \\
\hline $\mathrm{Hb} \mathrm{A}(\%)$ & 83.40 & 81.90 & 79.8 & 82.70 \\
\hline Hb A2 (\%) & 2.50 & 2.60 & 2.8 & 2.50 \\
\hline Hb Ottawa (\%) & 14.10 & 15.50 & 17.4 & 14.80 \\
\hline Genotype & $\begin{array}{c}\alpha \alpha / \alpha \alpha^{\text {Ottawa }} \\
\beta / \beta\end{array}$ & $\begin{array}{c}\alpha \alpha / \alpha \alpha^{\text {Ottawa }} \\
\beta / \beta\end{array}$ & $\begin{array}{c}\alpha \alpha / \alpha \alpha^{\text {Ottawa }} \\
\beta / \beta\end{array}$ & $\begin{array}{c}\alpha \alpha / \alpha \alpha^{\text {Ottawa }} \\
\beta / \beta\end{array}$ \\
\hline
\end{tabular}

RBC, red blood cell count; $\mathrm{Hb}$, hemoglobin; MCV, mean corpuscular volume; HCT, hematocrit; $\mathrm{MCH}$, mean corpuscular hemoglobin; MCHC, mean corpuscular hemoglobin concentration; RDW, red blood cell distribution width. 


\section{Discussion}

Guangdong province is a high-incidence area of thalassemia and abnormal hemoglobin. During this hemoglobin survey of 9745 students in the Chaozhou area of Guangdong, the incidence of $\mathrm{Hb}$ Ottawa was found to be $0.41 \%$ (4/9745). $\mathrm{Hb}$ G-Chinese [a30 (B11) Glu $\rightarrow$ Gln], Hb G-Waimanalo [ $\alpha 64$ Asp $\rightarrow$ Asn] and $\mathrm{Hb}$ Ottawa have the same electrophoresis phenomenon $(11,13)$. All are stable hemoglobin variants and their carriers usually do not present any clinical symptoms or hematological changes. Therefore, the differential diagnosis of $\mathrm{Hb}$ Ottawa from $\mathrm{Hb}$ G-Chinese and $\mathrm{Hb}$ G-Waimanalo mainly depends on the DNA sequence analysis of the amplified $\alpha_{2}$-globin gene. High performance liquid chromatography (HPLC), multiplex allele specific PCR, high-resolution melting (HRM) or polymerase chain reaction and restriction fragment length polymorphism (PCR-RFLP) can also be applied to the differential diagnosis of Hb Ottawa $(3,14,15)$. In addition, we confirmed that the cases of Hb Ottawa identified in our population were the result of a GGT $\rightarrow$ CGT mutation in codon 15 of the $\alpha_{2}$-globin gene, not the $\alpha_{1}$-globin gene as previously described (4,5). Diagnosis of these relevant abnormal hemoglobins is difficult to acheive by routine screening methods. The development of novel methods would be useful for providing an accurate and fast diagnosis.

\section{Acknowledgements}

This study was supported by the Medical Research Fund of Guangdong Province (nos. B2010348 and A2009781).

\section{References}

1. Vella F, Casey R and Lehmann H: Hemoglobin Ottawa: alpha 215 (A13) gly $\rightarrow$ arg beta 2. Biochim Biophys Acta 336: 25-29, 1974.
2. Pootrakul S, Srichivanont S and Wasi P: Hemoglobin Siam (alpha 215 arg beta 2): a new alpha-chain variant. Humangenetik 23: 199-204, 1974

3. Gu YC, Wilson JB and Webber BB: HB Ottawa [alpha 15 (A13) GLY $\rightarrow$ ARG] found in Hubei Province, People's Republic of China. J Tongji Med Univ 6: 185-187, 1986.

4. Yodsowan B, Svast J and Srisomsap C: Hb Siam [alpha15 (A13) Gly $\rightarrow$ Arg] is a GGT $\rightarrow$ CGT mutation in the alpha1-globin gene. Hemoglobin 24: 71-75, 2000.

5. Turbpaiboon C, Svasti S and Sawanqareetakul P: Hb Siam [alpha15 (A13) Gly $\rightarrow$ Arg (alpha1) (GGT $\rightarrow$ CGT)] is a typical alpha chain hemoglobinopathy without an alpha-thalassemic effect. Hemoglobin 26: 77-81, 2002.

6. Schneider RG: Differentiation of electrophoretically similar hemoglobins-such as S, D, G and P; or A2, C, E and O-by electrophoresis of the globin chains. Clin Chem 20: 1111-1115, 1974.

7. Carrell RW and Kay R: A simple method for the detection of unstable haemoglobins. Br J Haematol 23: 615-619, 1972.

8. Ockelford PA, Liang AY, Wells RM, Vissers M, Brennan SO, Williamson D and Carrell RW: Hemoglobin Volga, beta 27 (B9) Ala replaced by Asp: functional and clinical correlations of an unstable hemoglobin. Hemoglobin 4: 295-306, 1980.

9. Ohba Y, Hattori Y, Yoshinaka H, Matsuoka M, Miyaji T, Nakatsuji N and Hirano M: Urea polyacrylamide gel electrophoresis of PCMB precipitate as a sensitive test for the detection of the unstable hemoglobin subunit. Clin Chim Acta 119: 179-188, 1982.

10. Lin M, Wu JR, Yang LY, Zou HY, Wang Q and Zheng L: Hb Q-H disease: two cases in a Cantonese family. Blood Cells Mol Dis 41: 259-260, 2008

11. Lin M, Wu JR, Yang LY, Chen H, Wang PP, Wang Q and Zheng L: Hb G-Waimanalo: occurrence in combination with alpha-thalassemia-1 Southeast Asian deletion. Blood Cells Mol Dis 42: 36-37, 2009.

12. Huang Y, Lin M and Yang LY: Hb CS-H disease combined with $\beta$-thalassemia. Blood Cells Mol Dis 44: 215-216, 2010.

13. Wang PP, Lin M, Wu JR, Wang XY and Yang LY: Three cases of the hemoglobin G-Chinese variant detected in patients of southern Chinese origin. Mol Med Rep 3: 459-461, 2010.

14. Fucharoen S, Singsanan S and Hama A: Rapid molecular characterization of $\mathrm{Hb}$ Queens and $\mathrm{Hb}$ Siam: two variants easily misidentified as sickle Hb. Clin Biochem 40: 137-140, 2007.

15. Shih HC, Er TK and Chang TJ: Development of a high-resolution melting method for the detection of hemoglobin alpha variants. Clin Biochem 43: 671-676, 2010. 